\section{Motivational, emotional and memorable dimensions of non-Muslim tourists' halal food experiences}

\section{Non-Muslim tourists' halal food experiences

\author{
Erose Sthapit
}

Haaga-Helia University of Applied Sciences, Helsinki, Finland

Peter Björk

Hanken School of Economics - Vaasa Campus, Vaasa, Finland, and

Senthilkumaran Piramanayagam

Department of Allied Hospitality Studies, Manipal Academy of Higher Education, Manipal, India

Received 9 February 2021 Revised 21 March 2021 Accepted 28 June 2021

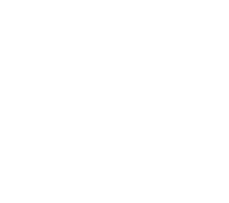

\begin{abstract}
Purpose - This study aims to explore non-Muslim tourists' general halal food preferences, motivations for tasting halal food during their recent trips, positive and negative emotions and memorable dimensions associated with their recent halal food experiences after returning from holiday.

Design/methodology/approach - Data were collected using the authors' personal networks and Amazon Mechanical Turk (MTurk) using a questionnaire. An email containing a link to the questionnaire was sent to the authors' personal networks and posted on MTurk in January 2021.

Findings - Of the 311 non-Muslim respondents, more than half considered themselves as food neophiliacs and considered halal food experiences as imperative whilst travelling. However, tasting halal food was not a major travel motivation. Novelty and taste were the two main motivations for tasting halal food whilst at a tourism destination. Emotions elicited by halal food experiences focussed on "joy" and "love". The proposed conceptual framework for memorable halal food experiences comprises several dimensions: taste, spending time with family and friends, novelty, quality and safety, hospitality, ambience (setting/servicescape) and experiencing others' culture through food.
\end{abstract}

Originality/value - This is one of the first studies to explore non-Muslim tourists' motives, emotions and memorable dimensions of halal food experiences.

Keywords Halal food, Non-Muslim tourist, Motivation, Emotion, Memorability

Paper type Research paper

\section{Introduction}

The interest of both Muslim and non-Muslim consumers in halal food, defined in this study as food that does not consist or contain anything that is considered unlawful according to Islamic law, as well as uses specific slaughter methods, has increased rapidly throughout

(C) Erose Sthapit, Peter Björk and Senthilkumaran Piramanayagam. Published by Emerald Publishing Limited. This article is published under the Creative Commons Attribution (CC BY 4.0) licence. Anyone may reproduce, distribute, translate and create derivative works of this article (for both commercial and non-commercial purposes), subject to full attribution to the original publication and authors. The full terms of this licence may be seen at http://creativecommons.org/licences/by/4.0/legalcode 
JIMA 14,1

the world (Secinaro and Calandra, 2020). The demand for halal food is growing not only due to the Muslim population but also amongst non-Muslims across Europe (Ayyub, 2015). In Islam, halal food products and services are allowed for Muslims according to Shariah standards, whereas other religions such as Hindu, Buddhist and Christian (non-Muslims) are also consuming halal food for their dietary health (Rahman et al., 2020). Non-Muslims are considered contributors to this flourishing sector (Rahman et al., 2020). For example, in Europe - mostly in the UK, France, Germany and Holland - halal restaurants attract many non-Muslim guests searching for exotic dishes and halal hygiene and safety standards (Al-Ansi and Han, 2019). Currently, halal food is considered a distinguished cuisine offered to Muslim and non-Muslim consumers and is made available at various outlets (Battour et al., 2021; Rahman et al., 2020) due to its high concerns on health, environmental and quality issues (Olya and Al-Ansi, 2018), including food standards associated with human welfare, sustainability and social justice (Zainalabidin et al., 2011).

Many non-Muslim destinations have integrated halal food culture and cuisine into their tourism products to attract a broader market segment of tourists and to differentiate themselves from competitors, for example, Thailand, Japan and South Korea (Secinaro and Calandra, 2020). Halal-themed events of local culinary traditions, lifestyles and heritage that are associated with Muslims attract both Muslim and non-Muslim tourists (Yousaf and Xiucheng, 2018). However, supply research has mainly addressed halal food consumption in the context of tourism, despite its importance (Jia and Chaozhi, 2021). Consequently, tourists' halal food experiences have remained relatively unexplored (Akhtar et al., 2020; Mannaa, 2020). The majority of studies on halal food experiences have been conducted amongst tourists of Muslim nationalities (Akhtar et al., 2020; Mannaa, 2020). There is a dearth of empirical studies exploring non-Muslim tourists' halal food experiences (Rahman et al., 2020; Wibowo et al., 2020), hence pinpointing a research gap and the focus of this study.

Food serves a social and cultural function (Mohsin et al., 2020), including a major component of a travel experience (Sthapit et al., 2019). Food is considered to be a major tourist motivation (Kim et al., 2019), but relatively little attention has been paid to examining tourists' motivations for consuming halal food (Al-Ansi and Han, 2019). Existing studies have mainly focussed on halal food quality (Jia and Chaozhi, 2021), halal-friendly destinations (Al-Ansi and Han, 2019), halal food certification (Takeshita, 2019), halal supply chain (Khan et al., 2019), halal orientation strategy (Zailani et al., 2019) and halal dining experiences of Muslim tourists (Akhtar et al., 2020; Mannaa, 2020). Tourists' motivations for halal food choices have been addressed using a limited theoretical approach (Battour et al., 2018). However, a holistic understanding of non-Muslim tourists' motivations for consuming halal food is lacking (Rahman et al., 2020).

Emotions play an important role in food consumption; food can make us happy or disgusted (Gmuer et al., 2015). Halal food experiences may trigger emotional reactions, both positive and negative (Mostafa, 2020) such as joy, surprise, sadness, anger, disgust and fear (Wu et al., 2014), which are elicited during consumption (Sthapit et al., 2017). Existing studies on emotions linked to tourists' food experiences have focussed on food festivals (Organ et al., 2015), restaurants (Levitt et al., 2019), specific destinations (Sthapit et al., 2019) and particular dishes (Kim et al., 2019). Other studies on tourist food consumption have considered the foodscape (Björk and Kauppinen-Räisänen, 2019) and its impact on other constructs (Sthapit et al., 2019). Consumer-centric studies on the emotional dimensions of non-Muslim tourist's halal food experiences are lacking (Mostafa, 2020).

Consumers' emotions significantly influence the evaluation of their experiences and positive emotions are associated with memorable experiences (Tung and Ritchie, 2011). Today, offering consumers memorable tourism experiences (MTEs) is key to being 
competitive in the tourism industry (Sthapit and Jiménez-Barreto, 2018). Kim et al. (2012) developed an instrument to examine the dimensions of an MTE. However, some recent studies indicate that one of the flaws attributed to Kim et al.'s (2012) MTE scale concerns the fact that it restricts the local culture dimension to social interactions, thereby neglecting the role of food as an essential element in memory formation (Sthapit et al., 2019). Only a handful of studies have linked the MTE concept with food, overlooking destination food experiences as a driver of MTEs (Sthapit et al., 2019). Although antecedents of memorable food experiences have been studied previously, little research has examined their dimensions in a halal food setting.

To bridge the gaps in the extant literature, the purpose of this study was fourfold:

(1) to explore non-Muslim tourists' general halal food preferences;

(2) to examine their motivations for tasting halal food during their recent trips;

(3) to explore the positive and negative emotions that non-Muslim tourists associate with their recent halal food experiences; and

(4) to build on the existing MTE and food experience research by examining the memorable positive and negative dimensions that non-Muslim tourists recall from their recent halal food experiences after returning from holiday.

It is worthwhile to explore non-Muslim tourists' general halal food preferences, motivations for tasting halal food during their recent trips, positive and negative emotions and memorable dimensions associated with their recent halal food experiences after returning from holiday. The findings of this stay may benefit both Halal food service providers and non-Muslim tourists. It helps Halal food service providers to enhance the probability of offering those experiences that are special, cherished and truly memorable. By offering memorable experiences, Halal food service providers can differentiate themselves and gain a competitive advantage over competitors. If Halal food service providers succeed in offering memorable experiences to non-Muslim tourists, the non-Muslim tourists benefit as well because they get a special food experience as opposed to a satisfactory experience.

\section{Literature review}

\section{Halal, halal tourism and halal food}

Halal is an Arabic word referring to what is permitted by Islamic teachings (Jia and Chaozhi, 2021; Wilson and Liu, 2011). In other words, halal means "lawful" or "permitted"; thus, halal tourism is a sector that seeks to support the essential values of Islam (Henderson, 2010). The opposite of halal is haram, which means prohibited, unlawful or illegal (Ali et al., 2017). Haram items can be divided into several main categories and include any products derived from or contaminated with these prohibited materials such as carrion, blood, pig, permitted animals slaughtered incorrectly and intoxicants (Soon et al., 2017).

Anything in the tourism industry that Islamic law permits Muslims to use or engage with is called "halal tourism" (Wardi et al., 2018). Halal tourism includes many components such as halal hotels, halal food and halal travel packages (El-Gohary, 2016). The objective of travel in Halal tourism is not necessary to be religious (Battour et al., 2021). Convergent opportunities exist in halal tourism, for example, travelling with family, seeking naturebased activities and visiting cultural attractions, museums and historical places (Mohsin et al., 2016). According to El-Gohary (2016), branding halal tourism as "Islamic tourism" might give the wrong impression that such tourism activities and/or products are only for Muslim customers, which is not true as non-Muslim customers can also consume halal tourism products for many reasons. 
JIMA 14,1

One of the critical elements of halal tourism is the availability of foods that are permissible for Muslim tourists (i.e. halal). Halal food assures tourists that animals have been slaughtered according to the zibah ritual (Mohsin et al., 2020). Halal food is acknowledged to be clean, hygienic and of good quality (Alzeera et al., 2018). Yousaf and Xiucheng (2018) indicated that countries in Asia, namely, Thailand, Japan and South Korea, market their countries as top destinations for Muslims through halal food culture and cuisine. Non-Muslim tourists - especially those who are seeking a health-conscious lifestyle and those who are socially aware of other cultures and societies - consume halal food, which makes this niche market a flourishing sector of the tourism industry (Stephenson, 2014).

\section{Tourist food consumption motivation and non-Muslim tourists' interest in halal food}

Motivations are defined as physical and psychological needs and desires. They include the overall power to inspire, control and integrate a person's behaviours and activities (Pearce, 2013). Food can represent an underlying motivation for visiting destinations (Hendijani, 2016). Food consumption motivations and tourism are inextricably linked. Food represents more than just filling one's stomach to satisfy daily physiological needs; it also provides emotional stimulation and is a major contributor to the overall travel experience (Björk and Kauppinen-Räisänen, 2016). Tourists' food consumption motivations in destinations are heterogeneous and are affected by attitudes and interests in food during their trips away from home (Chang et al., 2020).

Kim et al. (2019) adopted a grounded theory approach to explore the motivational factors behind food consumption in tourist destinations. Nine motivational factors were identified: exciting experience, escape from a routine, health concern, learning knowledge, authentic experience, togetherness, prestige, sensory appeal and physical environment. Another study by Lopez-Guzman et al. (2017) on food consumption motivations identified five dimensions: sensory appeal, cultural experience, exciting things, interpersonal relationships and health concerns.

Halal food is growing in popularity amongst non-Muslim consumers due to humane animal treatment concerns and the perception that halal food is healthier and safer (Rezai et al., 2012). There are also studies indicating that the major reasons for halal food consumption amongst non-Muslims include safety, hygiene, food quality and health-related issues (Abd-Latif et al., 2014; Haque et al., 2015). Studies indicate that non-Muslim consumers place great importance on quality food choices and selection due to concerns over health, ethics in food preparation and being green and environmentally friendly (Damit et al., 2018). Mathew et al. (2014) found that non-Muslims were attracted by elements in the halal concept of food, particularly hygiene and cleanliness, which are ultimately reflected in the quality of the halal food. Experiences of halal food consumption can also influence the positive perception of halal food (Damit et al., 2018).

\section{Tourists' emotional responses to food experiences and the link to memories}

In the field of tourism, emotions refer to tourists' emotional state during the tourist experience. Tourists tend to remember positive emotions more than negative emotions (Wirtz et al., 2003). Emotions result from hedonic consumption experiences (Addis and Holbrook, 2001), especially in the context of tourism, where expectations of pleasure are a great motivation for travel (Li et al., 2014). Generally, the eating habits of human beings are affected by emotions due to the effects of food, body, society and the natural environment (Desmet and Schifferstein, 2008). Favourite foods can cause positive emotions, whereas the least favoured dishes can cause negative emotions (Manzocco et al., 2013). Food experiences 
are perceived as a pleasurable vacation activity and arouse emotional reactions, both positive and negative (Mak et al., 2017).

Positive emotion is an immediate and transitory state that occurs during tourism (Lin and Kuo, 2016). Some studies have identified positive feelings such as excitement, happiness, pleasure, interest and relaxation, as tourism-related emotions (Kim et al., 2016). Positive emotions arising from a holiday experience enhance the memorability of the trip (Sthapit et al., 2017). However, travel can be stressful and associated with negative emotional outcomes (Mackenzie and Kerr, 2013). Negative emotions include depression, sadness, anger, tension, anxiety, pain, fear and hate (Yang and Hanks, 2016). Negative emotions are related to a lack of satisfaction and tourists may perceive a negative experience in either the tourist destination or in the quality of the service provided ( $\mathrm{Li}$ et al., 2015). Tourists may often feel negative emotions during their tourism experience, for example, due to the physical incongruence and unprofessional behaviour of the service provider (Sthapit et al., 2020). Emotions can affect both memory encoding and retrieval processes and are an important component of a (remembered) tourist experience (Knobloch et al., 2017).

Memory is an active, constructive process that links an experience to a tourist activity's emotive and perceptual outcomes (Oh et al., 2007). According to Sthapit et al. (2019), tourism experiences are meaningful only when individuals successfully remember experiences in the retrieval stage. Although on-site tourism experiences are momentary and may provide transitory feelings (Kim et al., 2012) and experience stored in memory is significant to travellers as it "holds a certain attraction and intrinsic reward that materialise in the moments of storytelling" (Neumann, 1999, pp. 179-180). Food experiences provide the tourist with a plethora of memories and often relate to particular moments (Sutton, 2001), that is, episodic memories, which include individuals' long-term storing of factual recollections concerning personal experiences (Schwartz, 2011). Episodic memories are thought to be the most interesting to study about tourist experiences (Larsen, 2007), considering that "lived experiences gather significance as we reflect on and give memory to them" (Curtin, 2005, p. 3). Tourists generally remember their vacations in a positive manner, which is associated with their positive emotional experiences during the vacation (Tung and Ritchie, 2011). However, if negative emotions are sufficiently intense, they can create negative memorable experiences (Sthapit et al., 2020).

\section{Methodology}

\section{Population sample, data collection and analysis}

This study used a qualitative approach to expand on both food tourism research and the role of memory in tourism by investigating halal food consumption motivation, emotions and what makes a halal food experience memorable. An empirical study was conducted using a self-administered open-ended questionnaire. The use of an open-ended questionnaire allowed respondents to describe their recent Halal food experiences in their own words, which it may not have been able to obtain from a closed questionnaire survey. The target population was non-Muslim tourists who had tasted halal food in the past 12 months. Convenience sampling was used, as it is cheap, efficient and simple to implement. The authors do acknowledge that the key disadvantage of this sampling technique is that the sample lacks clear generalisability. Data was collected from the authors' personal networks and Amazon Mechanical Turk (MTurk). The personal networks from which the sample was drawn for this study were made up of professionals and did not include very close social contacts (friends, family). An email containing a link to the questionnaire was sent to the authors' personal network and posted on MTurk in January 2021. The survey questionnaire link was active for four weeks. MTurk is an online marketplace designed to allow 
JIMA 14,1

individuals or groups to pay other individuals to complete small online tasks. According to Goodman et al. (2013), MTurk offers an inexpensive data collection method with highquality data and reliable results. Numerous tourism studies have used Murk for data collection (Harrigan et al., 2017; Jiménez-Barreto et al., 2019; Sthapit et al., 2020) and the amount of reward paid to respondents varies, for example, $\$ 0.30$ (Shim et al., 2015), $\$ 1.00$ (Sthapit et al., 2020), \$1.05 (Jiménez-Barreto et al., 2019) and \$1.50 (Harrigan et al., 2017). In this study, each participant was paid US\$1.00 for successfully completing the survey.

The first section included an introductory question with a "yes" or "no" option ("Did you taste halal food during your recent trip"?). Respondents who replied "no" to the introductory question were not included in the data analysis. The second section included questions relating to demographic variables (age, gender, marital status, nationality and religion) and trip characteristics (e.g. When did you have this trip?; "Recent destination visited"; "Duration of the recent stay"; "Travel companion"; "Number of people in the travel party during this recent trip"? "Purpose of visit"). The third section included questions about halal food preferences in general (e.g. "Are you generally interested in eating halal food and cooking”?). Respondents were then asked to recollect their latest halal food experience. The last section addresses their on-site halal food experience (e.g. halal food(s) tasted, setting of the experience, who participated in it, motivation for tasting halal food, emotions linked to this experience, overall food experience and what made this halal food experience most memorable). In total, 27 questions were included in the survey.

This study's key findings were based on qualitative responses to survey questions considering motivation, emotions and memories. The data analysis adopted a grounded theory research design (Glaser and Strauss, 1967). Based on Strauss and Corbin's (1990) study, we adopted three steps for a grounded theory approach. The first step was to scan the collected data to obtain a broad understanding of it; the second step was to review the data and list categories and the last step involved manual coding. As Strauss and Corbin (1990) recommended, three types of coding were used: open coding, axial coding and selective coding.

\section{Findings and discussion}

Profile of the respondents

Of the total 311 respondents, 187 were male and 124 were female. Their ages ranged from 19 to 67 years old. The largest age group was 19-29 years old (190). The majority of the participants were married (144) and single (137). In terms of nationality, the majority of them were Americans (189) and Indians (99). The respondents represented 11 different nationalities. Regarding religion, many were Christian (205), followed by Hindu (89).

Respondents' most recent trips took place between March 2020 and January 2021. The travel destinations included numerous locations ranging from Delhi to Paris. Many were repeat visitors to the destination (187) and others were first-timers (124). The duration of stay ranged from 1-60 days; most people reported spending more than five days (119), followed by five days (103) at the destination. The number of people in the travel party ranged from one to 15, with many of the respondents having travelled in groups of more than two people (206). In terms of the travel companion during this trip, many mentioned friends (108), other family members (63), husband or wife (59), alone (38), work colleagues (30) and others (13). A total of 257 respondents travelled for leisure, whereas the rest travelled for business (54) (Table 1).

\section{Food preferences}

In response to the question: "Are you generally interested in eating halal food and cuisine"? The majority of the respondents answered "yes" (235) and 76 reported "no". Regarding the 
Characteristics

Gender

Male

Female

Age

19-29

30-39

40-49

$>50$

Marital status

Married

Single

Divorced

Co-habitation

Engaged

Nationality

American

Indian

Sri Lankan

Mexican

British

Italian

Filipino

Haitian

Ecuadorian

Ethiopian

Chinese

Religion

Christian

Hindu

Buddhist

Sikh

Jain

Trips undertaken

During March-December 2020

During January 2021

Travel (to destination)

First-timers

Repeat visitors

Duration of stay (in days)

1

2

3

4

5

$>5$

Number of people at the travel party

1

2

$>2$
No. of respondents

187

124

190

51

44

26

144

137

15

11

4

189

101

9

4

2

1

1

1

1

1

1

205

89

10

4

3

293

18

187

124

6

20

35

28

103

119

36

69

206

(continued)
Non-Muslim tourists' halal food experiences

29

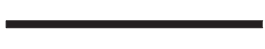




\begin{tabular}{|c|c|c|}
\hline $\begin{array}{l}\text { JIMA } \\
141\end{array}$ & Characteristics & No. of respondents \\
\hline 30 & $\begin{array}{l}\text { Travel companion } \\
\text { Friends } \\
\text { Other family members } \\
\text { Husband or wife } \\
\text { Alone } \\
\text { Work colleagues }\end{array}$ & $\begin{array}{r}108 \\
63 \\
59 \\
38 \\
30 \\
13\end{array}$ \\
\hline Table 1. & $\begin{array}{l}\text { Purpose of the trip } \\
\text { Leisure/tourism } \\
\text { Business }\end{array}$ & $\begin{array}{r}257 \\
54\end{array}$ \\
\hline
\end{tabular}

question: "Do you eat halal food whilst at home"? 158 responded yes and 153 reported no. The majority of the respondents (98) agreed with the statement "I am willing to taste something new", followed by "I am very willing to taste something new" (80), "I prefer familiar foods" (50), "I somewhat prefer familiar foods" (43) and "I very much prefer familiar foods" (40).

Mak et al. (2017) proposed that food-related personality traits are one of the factors that affect tourist food consumption. Food-related personality traits refer to individual characteristics that exert a pervasive influence on a broad range of food-related behaviours. In particular, two main types of traits can be identified from the tourism literature: food neophobia and variety-seeking (neophilia). Tourists exhibiting food neophilia traits have a desire to experience new food (Wolff and Larsen, 2019). Food neophiliacs are more inclined towards new food experiences and they possess different taste physiology, which enables them to gain a greater amount of pleasure from experiencing new foods (Kim et al., 2010). Thus, on the one hand, the majority of the respondents could be categorised as food neophiliacs $(57 \%)$, given that they exhibited a tendency to seek new food to taste.

On the other hand, others preferred familiar foods $(43 \%)$ and exhibited behaviour characteristic of food neophobia. Food neophobia is defined as the reluctance to eat and/or avoidance of novel foods (Pliner and Hobden, 1992) and a form of behaviour that rejects any unknown food proposals (Dimitrovski and Crespi-Vallbona, 2017). Food neophobia principally reflects humans' natural tendency to dislike or suspect new and unfamiliar foods (Pliner and Salvy, 2006). This finding supported studies indicating that not everybody is a voyaging gourmand (Wolff and Larsen, 2019). The two groups of respondents could be described as either novelty or familiarity seekers. This means that the tourists surveyed in this study were no more or less interested in or scared of unfamiliar food, which is consistent with earlier findings (Mak et al., 2017) but contrary to studies indicating that food neophobia is not very common amongst tourists (Wolff and Larsen, 2019).

In response to the question, "How important are Halal food experiences for you whilst travelling"? The majority reported it was not important (129), followed by important (109) and very important (73). Overall, the majority of the respondents considered halal food experience as imperative whilst travelling (182). This finding supports studies indicating that halal food is growing in popularity amongst non-Muslims (Lee et al., 2016; Damit et al., 2018) and is evident in this study.

\section{Local food experiences and motivation to travel}

In response to the question: "Was tasting Halal food one of the major motivations for you to undertake this particular trip"? More than half the respondents stated "no" (187) and the 
others stated "yes" (124). In other words, for many, tasting local food was a secondary reason for visiting the destination, whereas, for others, it was a primary motive and was considered to be very important or a "push factor" in planning their trip.

Regarding the question, "During this trip, what Halal food did you eat"? Respondents mentioned numerous food items ranging from chicken kabab, halal grilled turkey to mutton biryani. These local food experiences took place in restaurants (178), hotels (88), street-side eateries (33), food trucks (3), friend's houses (4), shopping malls (2), food courts (2) and guesthouses (1). This finding showed that local food experiences are not limited to tourists' halal food experiences traditional and typical restaurant settings, as indicated in recent studies (Sthapit, 2018; Stone et al., 2018). In response to the question: "Who participated in this halal food experience with you"? Many respondents mentioned family members (115), friends (101), other travellers (45), alone (32) and colleagues (18).

In response to the question: "What was your motivation for tasting halal food during this trip"? Many mentioned experiencing something new (81), whilst others stated taste (73), hygiene (43), safety (39), friend's suggestion (17), affordable price (10), hunger (10), experiencing local culture (8) and more ethical (2). Tourist experiences have been widely conceptualised as novelty seeking (Ji et al., 2016) and as destinations' culinary delicacies, in this context, halal food is believed to satisfy the pursuit of novelty and local culture (Long, 2004).

Novelty-seeking motivation modifies tourists' predisposed neophobic tendencies, motivating them to try novel and different foods, which they would not consume in their ordinary lives (Chang et al., 2011). Further, the sensory appeal is regarded as an essential criterion for food consumption motivation; people are most likely to consume food, which they evaluate as tasty (Lopez-Guzman et al., 2017). Moreover, the wholesomeness concept of halal, which covers not only the Shariah requirement but also the sustainability concept of hygiene, sanitation and safety aspect, motivates consumers (tourists) to taste halal food, particularly those who are concerned about food safety and healthy lifestyles (Bonne and Verbeke, 2007). Halal food places high concern on health, environmental and quality issues (Olya and Al-Ansi, 2018), including food standards linked to human welfare, sustainability and social justice (Zainalabidin et al., 2011). Furthermore, price is one of the key motivational dimensions underlying food consumption in tourism (Mak et al., 2017), whilst friends' suggestions can be associated with the presence of others during a trip. Travel companionship has been found to encourage travellers to be more accepting of a greater diversity of travel experiences (Torres, 2016) and dining companionship may facilitate food consumption whilst at the destination (Björk and Kauppinen-Räisänen, 2017).

\section{Emotions linked to local food experiences and their sources}

In response to the question "Which positive or negative emotions did you strongly feel during your Halal food experience"? Most respondents mentioned "joy" (170), whilst others reported, "love" (90), "no strong emotions" (35), "anger" (3), "excitement” (2), “content" (1), "interest" (1), "gratitude" (1), "pride" (1) and "serenity" (1). The feeling of joy was emphasised by the responses of two respondents:

"Joy. The food tasted very good and was enjoyable to eat. The people working at the restaurant were very understanding about my food allergies" (21, female, Christian, American, visiting New York);

"Joy. This was a positive emotion that I felt whilst eating Halal food because the food was delicious and good. I ate it throughout the trip" (48, female, Christian, American, visiting Egypt). 
JIMA 14,1

This finding suggested that tourists mainly experience positive emotions whilst consuming halal food at a tourism destination. Although studies have indicated that negative emotions are evoked when recalling past food experiences (Manzocco et al., 2013), we found little evidence of negative emotions in tourists' recollections of their halal food experiences. The negative emotion of anger was uncommon in the recollections, as tourist activities mainly encouraged them to relax and engage in social experiences (Servidio and Ruffolo, 2016).

In response to the questions: "Was your local food experience on this trip mainly positive or negative"? The majority of the respondents mentioned positive (297), whilst 14 mentioned negatively. This was highlighted by the following keywords: "positive", "mostly positive", "very positive", "great", "mainly positive" and "absolutely positive". The respondents' recollections of mainly positive halal food experiences could be attributed to the rosy view phenomenon. This phenomenon mitigates negative emotional responses and magnifies positive emotional responses in people's retrospective assessments of their emotional experiences (Mitchell et al., 1997).

\section{Memorable dimensions}

In response to the question, "What made this halal food experience the most memorable"? Different elements created a memorable local food experience besides the food served. Specifically, many of the respondents replied: "taste" (112). The significance of taste in respondents' halal food experiences was highlighted by keywords and phrases such as "unique taste", "rich taste", "spicy", "tasty”, "yummy taste”, "taste of course”, "divine taste", "rich taste", "taste of food was awesome", "loved the taste", "unfamiliar taste", "taste of the food", "new taste", "flavour" and "flavour of the food". This was further emphasised by the responses of two respondents who said:

"Halal food has a unique taste when compared to other cuisines. The fresh taste in the Jewel of Nizam amazes me every time. I have tasted halal food at many places in Hyderabad [...]" (24, male, visiting Hyderabad);

"[...] The taste of the dish was the most memorable moment. The chicken dish that we had was really good" (38, female, visiting Goa).

This finding indicated that tourists' experiences with food contributed to the development of "food memories", which are linked to the sensory attributes of the food (taste), supporting the studies indicating that people tend to look for particular attributes in food that engage one or more of their senses (Prescott et al., 2002). Sensory pleasure derived from food and eating is important in fulfilling the experiential component of the tourist experience (Hjalager and Richards, 2002). This finding is in line with assertions made by Chandralal and Valenzuela (2013) and Kauppinen-Räisänen et al. (2013), who stressed the significance of sensory stimulation in food tourism and its influence on the memorability of the trip.

Another key component that contributed to respondents' memorable halal food experiences was spending time with family and friends (82). The following keywords and phrases were used: "enjoying halal food with friends", "eating with friends was an unforgettable memory", "the eating experience with friends", "eating halal food with my family made it the most memorable", "eating and spending time with family", "eating with my family", "joyful experience with friends", "enjoyed it with my friends", "sharing food with my family" and "good times with family" highlight the significance of spending time with family and friends when consuming halal food. This is further highlighted by the response of two respondents: 
"What made this Halal food experience most memorable was eating it with my family [...]. We ended up at the restaurant and browsed through the menu. My parents and I wanted to try Halal food. Our mouths were on fire [. . . ]. Overall, I had a wonderful time and the food was delicious" (21, male, single, Christian, American, visiting Cordoba);

"It was memorable because I enjoyed it with my friends. It was delicious and takes me back to that place. It was an incredible time with my friends as we enjoyed a new dish that none of us had ever tired" (41, female, divorced, Christian, Ethiopian, visiting Tennessee).

This finding supported studies indicating the significance of "interaction value" or “togetherness” in tourists' food experiences (Goolaup and Mossberg, 2017). For example, Goolaup and Mossberg (2017) explained that an important holiday experience for tourists is socialising with friends and family whilst enjoying food. The finding can be linked to the concept of commensality, that is, the practice of eating together (Sobal and Nelson, 2003). Studies have indicated that the commensality of food experiences offers opportunities for conversations, storytelling, family activities and positive memory creation. Such experiences in a different setting from home can take on special significance and become the main highlight when recalling the travel experience (Schänzel and Lynch, 2016). Some studies have acknowledged the importance of "togetherness" in tourists' food experiences (Sthapit, 2017) and that recalled food experiences are typically related to communal eating (Kauppinen-Räisänen et al., 2013).

The third component that contributed to respondents' memorable halal food experiences included novelty (50). Interpretive codes such as "feeling of having something new", "new food", "dishes were all new to me", "something new that we are used to", "newness of the food", "new for my mouth pallet", "new dish that none of us had ever tried" and "completely new". The responses of two respondents further highlight this:

"Nice memories. I spent the whole day with my wife sightseeing. Then we had halal food for dinner. That was completely new. We enjoyed it and was definitely a memorable time" (58, male, married, Christian, American, visiting Chicago);

"I have not tried Halal food before, so the newness of the food was the most memorable part" (25, female, American, Christian, visiting Connecticut).

Novelty, characterised as something distinct from the routine or usual, new and unfamiliar, is fundamental and enjoyable in a tourism experience (Mitas and Bastiaansen, 2018). Some studies indicate that novel experiences can trigger strong emotions, which, in turn, increase the memorability of the experience (Skavronskaya et al., 2020). A recent study by Wei et al. (2019) indicated that novelty has a significant positive effect on the vividness of MTEs. Chandralal et al. (2015) study found that novel tourism experiences tend to be more memorable for travellers than the more usual and common tourist experiences.

Others mentioned quality and safety (37), hospitality (13) and ambience (10) and experiencing others' culture through food (7). This finding supports some studies indicating that the major reasons for halal food consumption amongst non-Muslims include safety, hygiene, food quality and health-related issues (Abd-Latif et al., 2014; Haque et al., 2015), which also contribute to the memorability of their recent halal food experience. Hospitality is recognised as one of the major success factors in the tourism industry (Chau and Yan, 2021). Hospitality represents a ubiquitous human behaviour intended to protect and honour visitors, which is a universal tradition of human society (Blain and Lashley, 2014). Hospitality experienced during a trip has been shown to contribute to visitors' memorable experiences (Chandralal and Valenzuela, 2013; Sthapit, 2017).

Ambience is the quality of the surrounding space that is perceived by customers and is made up of a set of elements such as lighting, music, scent and colour (Jang and Liu, 2008). Ambience is part of the servicescape or the physical environment of a service organisation 
JIMA 14,1

where the service transaction occurs (Bitner, 1992). Some studies suggest that servicescapes are important in the hospitality industry, as these elements have been shown to strongly influence cognitive and affective responses towards a service encounter (Mason and Paggiaro, 2012), including memorability (Sthapit, 2017).

Overall, food is a useful attraction through which tourists can experience local culture (Long, 2004) and connects tourists with a destination's unique way of life (Sthapit, 2017). Some studies indicate that the memorability of food experiences is influenced by the opportunity to experience local cultures (Lin and Mao, 2015).

\section{Conclusion}

Five main conclusions can be drawn from this research. Firstly, more than half of the nonMuslim respondents considered themselves food neophiliacs, given that they exhibited a tendency to seek new food to taste and considered halal food experiences as imperative whilst travelling. Many reported eating halal food whilst at home and were generally interested in eating halal food and cuisine. This finding supports Burch's (1969) spillover theory, in which routine everyday activities, in this context, eating halal food, are extended to a holiday environment. In other words, some tourists may display identical behaviours whilst at home and whilst on holiday and novelty may not necessarily be found only in new doings but also in new locales in which to engage in routine activities (Sthapit and Björk, 2017).

Secondly, more than half of the respondents reported that tasting halal food was not one of the major motivations for them to undertake their particular trips. Thus, for many, tasting local food functioned as a secondary reason for visiting the destination. However, many participated in a variety of food experiences whilst at the destination and the food items that they tasted ranged from chicken kabab, halal grilled turkey to mutton biryani. Novelty and taste were the two main motivations for tasting halal food whilst at a tourism destination. Other motivations included hygiene, safety, friend's suggestion, affordable price, hunger, experiencing local culture and being more ethical.

Thirdly, emotions elicited by halal food experiences focussed on "joy" and "love". Some studies have conceptualised such positive feelings relating to tourists' food consumption as having emotional value and constituting an important benefit that tourists obtain by food experienced at a destination (Choe and Kim, 2019). The finding is consistent with studies claiming that guests predominantly experience positive emotions whilst consuming local food (Sthapit, 2018; Sthapit et al., 2017) and that positive emotions are more common than negative emotions during a tourism experience. The negative emotion of anger was uncommon in respondents' recollections, as tourism activities mainly encouraged them to relax and engage in social experiences (Servidio and Ruffolo, 2016). The findings also support studies indicating that tourists' food consumption and positive emotions are related and interact to affect each other (Björk and Kauppinen-Räisänen, 2017) and that tasty encounters can evoke emotional recollections (Stone et al., 2018).

Fourthly, this study proposes a conceptual framework for memorable halal food experiences, which comprises several dimensions: taste, spending time with family and friends, novelty, quality and safety, hospitality, ambience (setting/servicescape) and experiencing others' culture through food. Non-Muslim tourists' memories of halal food experiences are influenced by the food (taste, novelty, quality and safety), people (interacting with family and friends and hospitality of the service provider) and the setting (ambience/servicescape) (Figure 1).

Finally, the findings suggest a possible link between motivations, emotions and memorable halal food experiences. It appears that the reasons for tasting halal food are hedonic and subjective rather than practical or objective, although a minority mentioned 


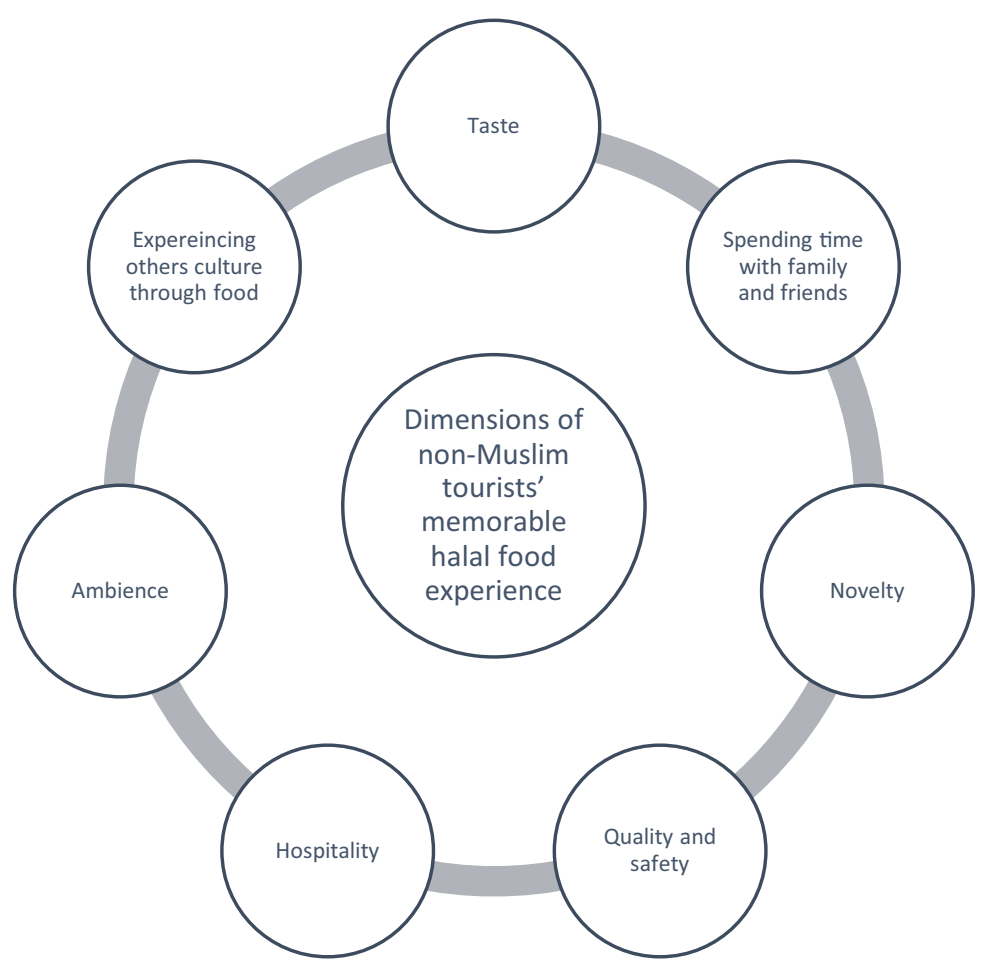

Non-Muslim
tourists' halal
food
experiences

35

affordable price (functional). According to the arousal theory of motivation, people are driven to perform actions to maintain an optimum level of emotional arousal (Berlyne, 1960). These emotional arousals are elicited by different appraisals (Nyer, 1960), of which goal congruence (motive consistency) elicits positive emotions. Some studies likewise indicate that visitors who are intrinsically motivated (push motivation) experience more positive emotions (Cini et al., 2013). For many tourists in the present study, their primary motives for tasting halal food were related to their internal desires, which might have contributed to their positive emotions of joy and love. These emotions shape tourists' memories of halal food experiences. However, given that some respondents experienced other emotions besides joy and love, including no strong emotions, the levels of emotional arousal brought about by the halal food experience in terms of intensity will not be at the same level for each tourist. For this reason, to create positive emotional arousal, which then feeds memories, tasting halal food as a primary motive whilst visiting a tourism destination might play an important role. Thus, push motivation to become an essential dimension in these interrelations.

The present study's main theoretical contributions include the identification of motivations, emotions and memorable dimensions linked associated with non-Muslim tourists' recent halal food experiences after returning from holiday. More specifically, the findings contribute to the existing studies on Halal food experiences and suggest that tourists' food consumption motivation is multidimensional, demonstrating that the desire to taste halal food whilst at a tourism destination arises from different factors and is not onedimensional. In addition, non-Muslim tourists mainly experienced positive emotions whilst 
JIMA 14,1

consuming Halal food. Moreover, the findings contribute to the existing studies on MTE by identifying taste, spending time with family and friends, novelty, quality and safety, hospitality, ambience and experiencing others' culture through food as crucial dimensions of non-Muslim tourists' memorable Halal food experiences.

This study has managerial implications for halal food service providers. Firstly, given that novelty and taste were the main motivations for tasting halal food whilst at a tourism destination, halal food service providers should be more traditional in their choice of ingredients for food preparation to maintain the newness and unique flavour of the dishes served to non-Muslim tourists. Halal food restaurants should focus on hygiene and safety issues. Halal food prices must be affordable and better descriptions of the halal foods, including information on recipes and methods of cooking in the menus, should be provided. This might help to promote halal cuisines and encourage visitors to specifically order halal food. Moreover, active interaction with customers and telling stories about the origin of halal food specialties, recipes and cooking methods should also be the focus of food service providers to elicit positive emotions. This will help tourists to know about the halal delicacies and the food culture. The servicescape should be spacious to serve both small and large customer groups and comfortable and attractive furnishings (ambience) would help encourage social interaction and the feeling of togetherness. Service providers should offer warm and welcoming hospitality to diners to prolong the memorability of their halal food experiences. Halal restaurants should also decorate their physical settings with stunning and unique cultural elements to wow tourists. Moreover, restaurants offering a large variety of halal foods with different flavours may have a competitive advantage over others and can best satisfy tourists' individual tastes.

Despite its contributions, this study has some limitations. The number of participants was limited and the study used a convenience-sampling technique; thus, the generalisability of the results is limited. Future studies should include a larger sample to address this issue. The present study collected data using an open-ended survey questionnaire, which might have had an impact on the richness of the gathered data. Adopting a wider range of research methods might overcome this research limitation. The study participants were mainly American and Indians, as well as young. Future studies would benefit from cross-cultural sample bases. The data was collected during the post-visit stage and relied on variable periods of memory. To avoid this incongruence between remembered experiences and onsite experiences, future studies should gather data from tourists immediately after their visit. Researchers could extend and augment the findings of this current study by comparing the halal food experiences of Muslim and non-Muslim tourists, including their impact on well-being. Finally, to test the reliability of memory recall, future studies should compare how tourists recall a service experience after coming back from a holiday and 6 or 12 months after the actual experience.

\section{References}

Abd-Latif, I., Mohamed, Z., Sharifuddin, J., Abdullah, A. and Ismail, M. (2014), “A comparative analysis of global halal certification requirements", Journal of Food Products Marketing, Vol. 20 No. 1, pp. 85-101.

Addis, M. and Holbrook, M.B. (2001), "On the conceptual link between mass customisation and experiential consumption: an explosion of subjectivity", Journal of Consumer Behaviour, Vol. 1 No. 1, pp. 50-66.

Akhtar, N., Jin, S., Henderson, A.,T.H. and Siddiqi, U.I. (2020), "Conflicting halal attributes at halal restaurants and consumers' responses: the moderating role of religiosity", Journal of Hospitality and Tourism Management, Vol. 45, pp. 499-510. 
Al-Ansi, A. and Han, H. (2019), "Role of halal-friendly destination performances, value, satisfaction, and trust in generating destination image and loyalty", Journal of Destination Marketing and Management, Vol. 13, pp. 51-60.

Ali, A., Xiaoling, G., Sherwani, M. and Ali, A. (2017), "Factors affecting halal meat purchase intention: evidence from international muslim students in China", British Food Journal, Vol. 119 No. 3, pp. 527-541.

Non-Muslim tourists' halal food experiences

Alzeera, J., Riederb, U. and Hadeeda, K.A. (2018), "Rational and practical aspects of halal and tayyib in the context of food safety", Trends in Food Science and Technology, Vol. 71, pp. 264-267.

Ayyub, R. (2015), "Exploring perceptions of non-Muslims towards halal foods in UK", British Food Journal, Vol. 117 No. 9, pp. 2328-2343.

Battour, M., Salaheldeen, M. and Mady, K. (2021), "Halal tourism: exploring innovative marketing opportunities for entrepreneurs", Journal of Islamic Marketing, Vol. 1.

Battour, M., Hakimian, F., Ismail, M. and Boğan, E. (2018), "The perception of non-Muslim tourists towards halal tourism: evidence from Turkey and Malaysia", Journal of Islamic Marketing, Vol. 9 No. 4, pp. 823-840.

Berlyne, D. (1960), Conflict, Arousal, and Curiosity, McGraw-Hill, New York, NY.

Bitner, M.J. (1992), "Servicescapes: the impact of physical surroundings on customers and employees", Journal of Marketing, Vol. 56 No. 2, pp. 57-71.

Björk, P. and Kauppinen-Räisänen, H. (2016), "Local food: a source for destination attraction", International Journal of Contemporary Hospitality Management, Vol. 28 No. 1, pp. 177-194.

Björk, P. and Kauppinen-Räisänen, H. (2017), "Interested in eating and drinking? How food affects travel satisfaction and the overall holiday experience", Scandinavian Journal of Hospitality and Tourism, Vol. 17 No. 1, pp. 9-26.

Björk, P. and Kauppinen-Räisänen, H. (2019), "Destination foodscape: a stage for travelers' food experience”, Tourism Management, Vol. 71, pp. 466-475.

Blain, M. and Lashley, C. (2014), "Hospitableness: the new service metaphor? Developing an instrument for measuring hosting", Research in Hospitality Management, Vol. 4 Nos 1/2, pp. 1-8.

Bonne, K. and Verbeke, W. (2007), "Values informing halal meat production and the delivery of halal credence quality", Agriculture and Human Values, Vol. 25 No. 1, pp. 35-47.

Burch, W.R. (1969), "The social circles of leisure: competing explanations", Journal of Leisure Research, Vol. 1 No. 2, pp. 125-147.

Chandralal, L. and Valenzuela, F. (2013), "Exploring memorable tourism experiences: antecedents and behavioral outcomes", Journal of Economics, Business and Management, Vol. 1 No. 2, pp. 177-181.

Chandralal, L., Rindfleish, J. and Valenzuela, F. (2015), "An application of travel blog narratives to explore memorable tourism experiences", Asia Pacific Journal of Tourism Research, Vol. 20 No. 6, pp. 680-693.

Chang, R.C.Y., Kivela, J. and Mak, A.H.N. (2011), "Attributes that influence the evaluation of travel dining experience: when east meets west", Tourism Management, Vol. 32 No. 2, pp. 307-316.

Chang, J., Morrison, A.M., Lin, S.H.H. and Ho, C.Y. (2020), "How do food consumption motivations and emotions affect the experiential values and well-being of foodies?", British Food Journal, Vol. 123 No. 2.

Chau, S.C. and Yan, L. (2021), "Destination hospitality indicators", Journal of Destination Marketing and Management, Vol. 19, p. 100537.

Choe, J. and Kim, S. (2019), "Development and validation of a multidimensional tourist's local food consumption value (TLFCV) scale", International Journal of Hospitality Management, Vol. 77, pp. 245-259.

Cini, F., Kruger, S. and Ellis, S. (2013), "A model of intrinsic and extrinsic motivations on subjective well-being: the experience of overnight visitors to a national park", Applied Research in Quality of Life, Vol. 8 No. 1, pp. 45-61. 
JIMA 14,1

Curtin, S. (2005), "Nature, wild animals and tourism: an experiential view", Journal of Ecotourism, Vol. 4 No. 1, pp. 1-15.

Damit, D.H.D.A., Harun, A., Martin, D., Shamsudin, A.S.B. and Kassim, A.W.M. (2018), "Non-Muslim consumers attitude and repurchase behaviour towards halal food: an application of buyer behaviour model", WSEAS Transactions on Business and Economics, Vol. 15, pp. 413-422.

Desmet, P.M. and Schifferstein, H.N. (2008), "Sources of positive and negative emotions in food experience", Appetite, Vol. 50 Nos 2/3, pp. 290-301.

Dimitrovski, D. and Crespi-Vallbona, M. (2017), "Role of food neophilia in food market tourists' motivational construct: the case of La boqueria in barcelona, Spain", Journal of Travel and Tourism Marketing, Vol. 34 No. 4, pp. 475-487.

El-Gohary, H. (2016), "Halal tourism, is it really halal?", Tourism Management Perspectives, Vol. 19, pp. $124-130$.

Glaser, B.G. and Strauss, A. (1967), The Discovery of Grounded Theory: Strategies for Qualitative Research, Aldine, Chicago.

Gmuer, A., Guth, J.N., Runte, M. and Siegrist, M. (2015), "From emotions to language: application of a systematic, linguistic-based approach to design a food-associated emotions lexicon", Food Quality and Preference, Vol. 40, pp. 77-86.

Goolaup, S. and Mossberg, M. (2017), "Exploring the concept of extraordinary related to food tourists' nature-based experience", Scandinavian Journal of Hospitality and Tourism, Vol. 17 No. 1, pp. 27-43.

Goodman, J.K., Cryder, C.E. and Cheema, A. (2013), "Data collection in a flat world: the strengths and weaknesses of mechanical turk samples", Journal of Behavioral Decision Making, Vol. 26 No. 3, pp. 213-224.

Haque, A., Sarwar, A., Yasmin, F., Tarofder, A. and Hossain, M. (2015), "Non-Muslim consumers' perception toward purchasing halal food products in Malaysia", Journal of Islamic Marketing, Vol. 6 No. 1, pp. 133-147.

Harrigan, P., Eves, U., Miles, M. and Daly, T. (2017), “Customer engagement with tourism social media brands", Tourism Management, Vol. 59, pp. 597-609.

Henderson, J.C. (2010), "Sharia-compliant hotels", Tourism and Hospitality Research, Vol. 10 No. 3, pp. 246-254.

Hendijani, R.B. (2016), "Effect of food experience on tourist satisfaction: the case of Indonesia", International Journal of Culture, Tourism and Hospitality Research, Vol. 10 No. 3, pp. 272-282.

Hjalager, A.M. and Richards, G. (2002), "Still undigested: research issues in tourism and gastronomy", in Hjalager, A.M. and Richards, G. (Eds), Tourism and Gastronomy, Routledge, London, pp. 224-234.

Jang, S.C. and Liu, Y. (2008), "Perceptions of Chinese restaurants in the US: what affects customer satisfaction and behavioral intentions?", International Journal of Hospitality Management, Vol. 28, pp. 338-348.

Ji, M., Wong, I.A., Eves, A. and Scarles, C. (2016), "Food-related personality traits and the moderating role of novelty-seeking in food satisfaction and travel outcomes", Tourism Management, Vol. 57, pp. 387-396.

Jia, X. and Chaozhi, Z. (2021), "Turning impediment into attraction: a supplier perspective on halal food in non-Islamic destinations", Journal of Destination Marketing and Management, Vol. 19, p. 100517.

Jiménez-Barreto, J., Sthapit, E., Rubio, N. and Campo, S. (2019), "Exploring the dimensions of online destination brand experience: Spanish and North American tourists' perspectives", Tourism Management Perspectives, Vol. 31, pp. 348-360.

Kauppinen-Räisänen, H., Gummerus, J. and Lehtola, K. (2013), "Remembered eating experiences described by the self, place, food, context and time", British Food Journal, Vol. 115 No. 5, pp. 666-685. 
Khan, S., Khan, M.I., Haleem, A. and Jami, A.R. (2019), "Prioritising the risks in Halal food supply chain: an MCDM approach", Journal of Islamic Marketing, Vol. (ahead-of-print)

Kim, D., Lee, C.K. and Sirgy, M.J. (2016), "Examining the differential impact of human crowding versus spatial crowding on visitor satisfaction at a festival", Journal of Travel and Tourism Marketing, Vol. 33 No. 3, pp. 293-312.

Kim, S., Park, E. and Lamb, D. (2019), "Extraordinary or ordinary? Food tourism motivations of japanese domestic noodle tourists", Tourism Management Perspectives, Vol. 29, pp. 176-186.

Kim, J.H., Ritchie, J.R.B. and McCormick, B. (2012), "Development of a scale to measure memorable tourism experiences", Journal of Travel Research, Vol. 51 No. 1, pp. $12-25$.

Kim, Y.G., Suh, B.W. and Eves, A. (2010), "The relationships between food-related personality traits, satisfaction, and loyalty among visitors attending food events and festivals", International Journal of Hospitality Management, Vol. 29 No. 2, pp. 216-226.

Knobloch, U., Robertson, K. and Aitken, R. (2017), "Experience, emotion, and eudaimonia: a consideration of tourist experiences and well-being", Journal of Travel Research, Vol. 56 No. 5 , pp. 651-662.

Larsen, S. (2007), "Aspects of a psychology of the tourist experience", Scandinavian Journal of Hospitality and Tourism, Vol. 7 No. 1, pp. 7-18.

Lee, S.-H., Siong, K.-C., Lee, K.-S. and Kim, H.-S. (2016), “Non-Muslim customers' purchase intention on halal food products in Malaysia”, Culinary Science and Hospitality Research, Vol. 22 No. 1, pp. 108-116.

Levitt, J.A., Meng, F., Zhang, P. and DiPietro, R.B. (2019), "Examining factors influencing food tourist intentions to consume local cuisine", Tourism and Hospitality Research, Vol. 19 No. 3, pp. 337-350.

Li, M., Lehto, X. and Wei, W. (2014), "The hedonic value of hospitality consumption: evidence from spring break experiences", Journal of Hospitality Marketing and Management, Vol. 23 No. 2, pp. 99-121.

Li, S., Scott, N. and Walters, G. (2015), "Current and potential methods for measuring emotion in tourism experiences: a review", Current Issues in Tourism, Vol. 18 No. 9, pp. 805-827.

Lin, C.H. and Kuo, B.Z.L. (2016), "The behavioral consequences of tourist experience", Tourism Management Perspectives, Vol. 18, pp. 84-91.

Lin, L. and Mao, P.C. (2015), "Food for memories and culture - a content analysis study of food specialties and souvenirs", Journal of Hospitality and Tourism Management, Vol. 22, pp. 19-29.

Long, L.M. (2004), Culinary Tourism, University Press of KY, Lexington.

Lopez-Guzman, T., Serrano Lopez, A.L., Perez Galvez, J.C. and Carpio Alvarez, S.D. (2017), "Food motivations in a tourist destination: North American tourists visiting the city of cuenca, Ecuador", Journal of International Food and Agribusiness Marketing, Vol. 29 No. 4, pp. 308-327.

Mackenzie, S.H. and Kerr, J.H. (2013), "Stress and emotions at work: an adventure tourism guide's experiences”, Tourism Management, Vol. 36, pp. 3-14.

Mak, A.H.N., Lumbers, M., Eves, A. and Chang, R.C.Y. (2017), "The effects of food-related personality traits on tourist food consumption motivations", Asia Pacific Journal of Tourism Research, Vol. 22 No. 1, pp. 1-20.

Mannaa, M.T. (2020), "Halal food in the tourist destination and its importance for muslim travelers", Current Issues in Tourism, Vol. 23 No. 17, pp. 2195-2206.

Manzocco, L., Rumignani, A. and Lagazio, C. (2013), "Emotional response to fruit salads with different visual quality", Food Quality and Preference, Vol. 28 No. 1, pp. 17-22.

Mason, M.C. and Paggiaro, A. (2012), "Investigating the role of festivalscape in culinary tourism: the case of food and wine events", Tourism Management, Vol. 33 No. 6, pp. 1329-1336.

Mathew, V.N., Abdullah, A.M.R.A. and Ismail, S.N.B.M. (2014), "Acceptance on halal food among NonMuslim consumers”, Procedia - Social and Behavioral Sciences, Vol. 121, pp. 262-271. 
JIMA 14,1

Mitas, O. and Bastiaansen, M. (2018), "Novelty: a mechanism of tourists' enjoyment", Annals of Tourism Research, Vol. 72, pp. 98-108.

Mitchell, T.R., Thompson, L., Peterson, E. and Cronk, R. (1997), "Temporal adjustments in the evaluation of events: the rosy view", Journal of Experimental Social Psychology, Vol. 33 No. 4, pp. 421-448.

Mostafa, M.M. (2020), "Global halal food discourse on social media: a text mining approach", The Journal of International Communication, Vol. 26 No. 2, pp. 211-237.

Mohsin, A., Ramli, N. and Abdulaziz, B.A. (2016), "Halal tourism: emerging opportunities", Tourism Management Perspectives, Vol. 19, pp. 137-143.

Mohsin, A., Brocado, A. and Rodrigues, H. (2020), "Halal tourism is traveling fast: community perceptions and implications", Destination Marketing and Management, Vol. 18, p. 100503.

Neumann, M. (1999), On the Rim: Looking for the Grand Canyon, University of MN Press, Minneapolis.

Nyer, P. (1960), "A study of the relationships between cognitive appraisals and consumption emotions", Journal of the Academy of Marketing Science, Vol. 25 No. 4, pp. 296-304.

Oh, H., Fiore, A.M. and Jeoung, M. (2007), "Measuring experience economy concepts: tourism applications", Journal of Travel Research, Vol. 46 No. 2, pp. 119-132.

Olya, H.G. and Al-Ansi, A. (2018), "Risk assessment of halal products and services: implication for tourism industry", Tourism Management, Vol. 65, pp. 279-291.

Organ, K., Koenig-Lewis, N., Palmer, A. and Probert, J. (2015), "Festivals as agents for behaviour change: a study of food festival engagement and subsequent food choices", Tourism Management, Vol. 48, pp. 84-99.

Pearce, P.L. (2013), The Social Psychology of Tourist Behaviour: International Series in Experimental Social Psychology, Elsevier, New York, NY.

Pliner, P. and Hobden, K. (1992), "Development of a scale to measure the trait of food neophobia in humans", Appetite, Vol. 19 No. 2, pp. 105-120.

Pliner, P. and Salvy, S. (2006), "Food neophobia in humans", in Shepherd, R. and Raats, M. (Eds), The Psychology of Food Choice, CABI. Wallingford pp. 75-92.

Prescott, J., Young, O., O’Neil, L., You, N.J.N. and Stevens, R. (2002), "Motives for food choice: a comparison of consumers from Japan, Taiwan, Malaysia and New Zealand", Food Quality and Preference, Vol. 13 Nos 7/8, pp. 489-495.

Rahman, M., Moghavvemi, S., Thirumoorthi, T. and Rahman, M.K. (2020), "The impact of tourists' perceptions on halal tourism destination: a structural model analysis", Tourism Review, Vol. 75 No. 3, pp. 575-594.

Rezai, G., Mohamed, Z. and Shamsudin, M.N. (2012), "Non-muslim consumers' understanding of halal principles in Malaysia”, Journal of Islamic Marketing, Vol. 3 No. 1, pp. 35-46.

Schänzel, H.A. and Lynch, P.A. (2016), "Family perspectives on social hospitality dimensions whilst on holiday", Tourist Studies, Vol. 16 No. 2, pp. 133-150.

Schwartz, B. (2011), Memory: Foundations and Applications, Sage Publications, Thousand Oaks.

Secinaro, S. and Calandra, D. (2020), "Halal food: structured literature review and research agenda", British Food Journal, Vol. 123 No. 1, pp. 225-243.

Servidio, R. and Ruffolo, I. (2016), "Exploring the relationship between emotions and memorable tourism experiences through narratives", Tourism Management Perspectives, Vol. 20, pp. $151-160$.

Shim, C., Vargas, P.T. and Santos, C.A. (2015), "Oriental imagery and American attitudes toward Asia: an exploratory tourism study”, Journal of Tourism and Cultural Change, Vol. 13 No. 2, pp. 165-181.

Skavronskaya, L., Moyle, B. and Scott, N. (2020), "The experience of novelty and the novelty of experience", Frontiers in Psychology, Vol. 11, p. 322. 
Sobal, J. and Nelson, M.K. (2003), "Commensal eating patterns: a community study”, Appetite, Vol. 41 No. 2, pp. 181-190.

Soon, J.M., Chandia, M. and Regenstein, J.M. (2017), "Halal integrity in the food supply chain”, British Food Journal, Vol. 119 No. 1, pp. 39-51.

Stephenson, M.L. (2014), "Deciphering Islamic hospitality: developments, challenges and opportunities", Tourism Management, Vol. 40, pp. 155-164.

Sthapit, E. (2017), "Exploring tourists' memorable food experiences: a study of visitors to santa's official hometown", Anatolia, Vol. 28 No. 3, pp. 404-421.

Sthapit, E. (2018), "Is there more to the effects of tourists' local food consumption on post-consumption behaviour?", Anatolia, Vol. 29 No. 4, pp. 614-616.

Sthapit, E. and Björk, P. (2017), "Activity participation home and away - examining the spillover theory among families on holiday", Anatolia, Vol. 28 No. 2, pp. 209-223.

Sthapit, E. and Jiménez-Barreto, J. (2018), "Exploring tourists' memorable hospitality experiences: an airbnb perspective", Tourism Management Perspectives, Vol. 28, pp. 83-92.

Sthapit, E., Björk, P. and Coudounaris, D.N. (2017), "Emotions elicited by local food consumption, memories, place attachment and behavioural intentions", Anatolia, Vol. 28 No. 3, pp. 363-380.

Sthapit, E., Björk, P. and Jiménez Barreto, J. (2020), "Negative memorable experience: North American and British airbnb guests' perspectives", Tourism Review, Vol. 76 No. 3.

Sthapit, E., Coudounaris, D.N. and Björk, P. (2019), "Extending the memorable tourism experience construct: an investigation of memories of local food experiences", Scandinavian Journal of Hospitality and Tourism, Vol. 19 Nos 4/5, pp. 333-353.

Stone, M.J., Soulard, J., Migacz, S. and Wolf, E. (2018), "Elements of memorable food, drink, and culinary tourism experiences", Journal of Travel Research, Vol. 57 No. 8, pp. 1121-1132.

Strauss, A. and Corbin, J. (1990), Basics of Qualitative Research: Grounded Theory Procedures and Techniques, Sage, Newbury Park.

Sutton, D. (2001), Remembrance of Repasts: An Anthropology of Food and Memory, Berg, Oxford.

Takeshita, S. (2019), "Halal certification or ingredient disclosure: a comparative analysis of serving food in japanese tourist destinations", Journal of Islamic Marketing, Vol. 11 No. 3, pp. 765-781.

Torres, E.N. (2016), "Guest interactions and the formation of memorable experiences: an ethnography", International Journal of Contemporary Hospitality Management, Vol. 28 No. 10, pp. 2132-2155.

Tung, V.W. and Ritchie, J.R. (2011), "Exploring the essence of memorable tourism experiences", Annals of Tourism Research, Vol. 38 No. 4, pp. 1367-1386.

Wardi, Y., Abror, A. and Trinanda, O. (2018), "Halal tourism: antecedent of tourist's satisfaction and word of mouth (WOM)", Asia Pacific Journal of Tourism Research, Vol. 23 No. 5, pp. 463-472.

Wei, C., Zhao, W., Zhang, C. and Huang, K. (2019), "Psychological factors affecting memorable tourism experiences", Asia Pacific Journal of Tourism Research, Vol. 24 No. 7, pp. 619-632.

Wibowo, M.W., Permana, D., Hanafiah, A., Ahmad, F.S. and Ting, H. (2020), "Halal food credence: do the malaysian non-Muslim consumers hesitate?”, Journal of Islamic Marketing, Vol. ahead-of-print No. ahead-of-print.

Wilson, J.A.J. and Liu, J. (2011), "The challenges of Islamic branding: navigating emotions and halal", Journal of Islamic Marketing, Vol. 2 No. 1, pp. 28-42.

Wirtz, D., Kruger, J., Scollon, C.N. and Diener, E. (2003), "What to do on spring break? The role of predicted, on-line, and remembered experience in future choice", Psychological Science, Vol. 14 No. 5, pp. 520-524.

Wolff, K. and Larsen, S. (2019), "Are food-neophobic tourists avoiding destinations?", Annals of Tourism Research, Vol. 76, pp. 346-349. 
JIMA

14,1

Wu, Y., Yang, Y. and Chiu, C. (2014), "Responses to religious norm defection: the case of Hui Chinese Muslims not following the halal diet", International Journal of Intercultural Relations, Vol. 39, pp. 1-8.

Yang, W. and Hanks, L. (2016), "Preconsumption mood, causal explanations, and post recovery reactions", Journal of Hospitality Marketing and Management, Vol. 25 No. 1, pp. 69-90.

Yousaf, S. and Xiucheng, F. (2018), "Halal culinary and tourism marketing strategies on government websites: a preliminary analysis", Tourism Management, Vol. 68, pp. 423-443.

Zailani, S., Iranmanesh, M., Jafarzadeh, S. and Foroughi, B. (2019), "The influence of halal orientation strategy on financial performance of halal food firms: halal culture as a moderator", Journal of Islamic Marketing, Vol. 11 No. 1, pp. 31-49.

Zainalabidin, M., Golnaz, R. and Mad, N.S. (2011), "The complementary effect of halal principles and sustainable concept", Journal of Environmental Science and Engineering, Vol. 5 No. 5, pp. 652-659.

\section{Further reading}

Capiola, A. and Raudenbush, B. (2012), "The effects of food neophobia and food neophilia on diet and metabolic processing", Food and Nutrition Sciences, Vol. 03 No. 10, pp. 1397-1403.

Holtzman, J.D. (2006), "Food and memory", Annual Review of Anthropology, Vol. 35 No. 1, pp. 361-378.

Mostafa, M.M. (2018), "Mining and mapping halal food consumers: a geo-located twitter opinion polarity analysis", Journal of Food Products Marketing, Vol. 24 No. 7, pp. 858-879.

\section{Corresponding author}

Erose Sthapit can be contacted at: erose.sthapit@haaga-helia.fi

For instructions on how to order reprints of this article, please visit our website: 